\title{
Profil Penggunaan Obat Antibiotik di Puskesmas Cakranegara Periode Januari - Juni 2021
}

\author{
Nur Oktaviani ${ }^{1 *}$ dan Anisatun Ramadhan ${ }^{1}$ \\ ${ }^{1}$ Jurusan Farmasi, Universitas Nahdlatul Wathan, Mataram, Indonesia \\ *Email : nuroktaviani8485@gmail.com
}

\begin{abstract}
Abstrak : Intensitas penggunaan antibiotik yang relatif tinggi menimbulkan berbagai permasalahan dan merupakan ancaman global bagi kesehatan terutama resistensi bakteri terhadap antibiotik. Tujuan penelitian ini adalah untuk mengetahui gambaran penggunaan obat antibiotik di Puskesmas Cakranegara. Penelitian ini dilaksanakan pada bulan Juli 2021 yang berlokasi di Puskesmas Cakranegara. Metode penelitian yang digunakan adalah metode penelitian deskriptif. Metode penelitian deskriptif berarti data yang telah di dapatkan di deskripsikan secara objektif dengan memaparkan fenomena dengan bantuan tabel atau gambar.

Berdasarkan hasil penelitian yang telah dilakukan menunjukan bahwa jumlah antibiotik yang digunakan di Puskesmas Cakranegara periode Januari - Juni 2021 sebanyak 56.785. Dan dengan Penggunaan Antibiotik meliputi Amoxicillin tablet sebanyak 47.209, Kotrimoxazole tablet sebanyak 4.161, Ciprofloxacin sebanyak 2.695, Amoxicillin sirup kering sebanyak 850, Metronidazole sebanyak 515, Kotrimoxazole sirup sebanyak 436, Kloramfenikol kapsul sebanyak 325, Oxytetrasiklin sebanyak 269, Gentamisin Sk sebanyak 142, Kloramfenikol tetes telinga sebanyak 106, Ampicillin sebanyak 80 dan Azitromicin sebanyak 14. Dengan penggunaan antibiotik terbanyak yaitu Amoxicillin tablet sebanyak 47.209.
\end{abstract}

Kata kunci : Antibiotik, Puskesmas Cakranegara, Profil Penggunaan Obat Antibiotik

\section{Pendahuluan}

Antibiotik disebut sebagai obat yang digunakan untuk mengobati infeksi akibat bakteri, dan juga membantu sistem pertahanan alami tubuh untuk mengeliminasi bakteri tersebut. Antibiotik digunakan dalam pengobatan pada manusia sudah dimulai sejak tahun 1940. Hal ini mengakibatkan meluasnya potensi resistensi bakteri (Amin, 2017). Menurut Juwono (2019), penggunaan antibiotik yang berlebihan dan pada beberapa kasus yang tidak tepat guna menyebabkan masalah kekebalan antibiotik, meningkatkan biaya pengobatan dan efek samping antibiotik (Juwono, 2019).

Antibiotik merupakan antibakteri yang dihasilkan dari mikroorganisme atau yang diperoleh dari sintesis yang berasal dari senyawa non organik. Adapun antibiotik dapat dikelompokan menjadi 8 golongan yaitu golongan Penilisilin, golongan Sefalosporin, golongan Aminoglikosida, golongan Quinolon, golongan Tetrasiklin, golongan Makrolida, dan Limkomisin, golongan Polipeptida dan golongan antibiotik lainnya.

Penyakit infeksi masih merupakan salah satu masalah kesehatan masyarakat yang penting, khususnya di negara berkembang. Salah satu obat andalan untuk mengatasi masalah tersebut adalah Antimikroba antara lain antibakteri/antibiotik, antijamur, antivirus, antiprotozoa. Antibiotik merupakan obat yang paling banyak digunakan pada infeksi yang disebabkan oleh bakteri. Berbagai studi menemukan bahwa sekitar 40-62\% antibotik digunakan secara tidak tepat antara lain untuk penyakit-penyakit yang sebenarnya tidak memerlukan antibiotik. Pada penelitian kualitas penggunaan antibiotik di berbagai bagian rumah sakit ditemukan 30\% sampai dengan $80 \%$ tidak didasarkan pada indikasi (Hadi, 2019).

Obat antimikroba adalah substansi yang menghambat pertumbuhan atau membunuh bakteri atau mikroorganisme lain (organisme mikroskopik termasuk bakteri, virus, jamur, protozoa, dan riketsia). Secara tehnik, istilah antibiotik mengacu pada zat kimia yang dihasilkan oleh suatu macam mikroorganisme yang menghambat pertumbuhan atau membunuh mikroorganisme lain. Bakteri dapat menjadi sensitif atau resisten terhadap antibakterial tertentu. Jika suatu bakteri resisten terhadap suatu antibakterial, maka organisme itu akan terus bertumbuh meskipun telah dilakukan pemberian obat antibakterial (Joyce \& Evelyn, 2018).

Intensitas penggunaan antibiotik yang relatif tinggi menimbulkan berbagai permasalahan dan merupakan ancaman global bagi kesehatan terutama resistensi bakteri terhadap antibiotik. Selain berdampak pada mordibitas dan mortalitas, juga memberi dampak negatif terhadap ekenomi dan sosial yang sangat tinggi. Pada awalnya resistensi terjadi di tingkat rumah sakit, tetapi lambat laun juga berkembang dikalangan masyarakat, khususnya Streptococcus pneumonia, Staphylococcus aureus, dan Escherica coli (Kemenkes, 2016).

Masyarakat mendapatkan obat termasuk antibiotik dari sarana pelayanan kesehatan seperti rumah sakit,apotik, puskesmas dan lain-lain. Puskesmas melakukan permintaan obat ke Instalasi 
Farmasi Kabupaten/Kota (IFK) dengan menggunakan Laporan Pemakaian dan Lembar Permintaan Obat (LPLPO).

\section{Metode Penelitian}

Jenis penelitian yang digunakan dalam penelitian ini adalah non eksperimental dengan metode penelitian deskriptif, pengumpulan data menggunakan data LPLPO dan profil puskesmas.

\section{Hasil dan Pembahsan}

Profil Penggunaan Antibiotik di Puskesmas Cakranegara Periode Januari-Juni 2021

Penelitian ini merupakan jenis penelitian non eksperimental dengan metode penelitian deskriptif. Penelitian deskriptif berarti data yang telah didapatkan dideskriptifkan secara objektif dengan memaparkan fenomena dengan bantuan tabel atau gambar.

Tabel Distribusi Total Penggunaan Obat Antibiotik di Puskesmas Cakranegara Periode Januari-Juni 2021.

\begin{tabular}{|c|l|c|}
\hline No & Nama Antibiotik & $\begin{array}{c}\text { Total Penggunaan } \\
\text { Antibiotik periode } \\
\text { Januari-Juni 2021 }\end{array}$ \\
\hline 1 & Amoxicillin tab & 47.209 \\
\hline 2 & Kotrimoxazol tab & 4.161 \\
\hline 3 & Ciprofloxacin & 2.695 \\
\hline 4 & $\begin{array}{l}\text { Amoxicillin sirup } \\
\text { kering }\end{array}$ & 850 \\
\hline 5 & Metronidazole & 515 \\
\hline 6 & $\begin{array}{l}\text { Kotrimoxazol } \\
\text { sirup }\end{array}$ & 436 \\
\hline 7 & $\begin{array}{l}\text { Kloramfenikol } \\
\text { kapsul }\end{array}$ & 325 \\
\hline 8 & Oxytetrasiklin & 269 \\
\hline 9 & Gentamicin Sk & 142 \\
\hline 10 & $\begin{array}{l}\text { Kloramfenikol } \\
\text { tetes telinga }\end{array}$ & 106 \\
\hline 11 & Ampicillin & 80 \\
\hline 12 & Azitromicin & $\mathbf{5 6 . 7 8 5}$ \\
\hline & Total & \\
\hline
\end{tabular}

Berdasarkan tabel di atas terlihat bahwa di Puskesmas Cakranegara dengan total Penggunaan Obat Antibiotik periode Januari-Juni 2021 yaitu 56.785 dengan penggunaan Antibiotik yang terbanyak yaitu Amoxicillin tablet. Penggunaan Antibiotik banyak digunakan pada 6 bulan awal tahun 2021 yaitu Bulan Januari-Juni dikarenakan penyakit Infeksi dan non Infeksi misalnya seperti penyakit ISPA (Infeksi Saluran Pernafasan Atas) terutama pada pandemi COVID-19. Meskipun ada beberapa penyakit pada saluran pernafasan yang tidak selalu memerlukan Antibiotik, tetapi jika penyakit tersebut sudah melewati tiga hari maka Dokter tetap meresepkan penggunaan Antibiotik.

\section{Total Pemakaian Antibiotik}

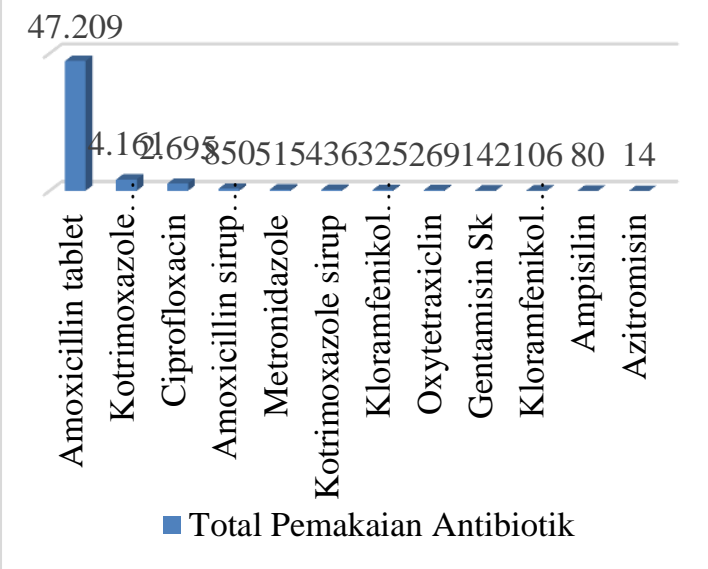

Dari Diagram batang di atas dapat dilihat bahwa penggunaan Antibiotik terbanyak yaitu Amoxicillin tablet sebanyak 47.209 tablet. Penyakit terbanyak dalam penggunaan Antibiotik tersebut yaitu seperti penyakit ISPA (Infeksi Saluran Pernafasan Atas) terutama pada pandemi COVID19.

\section{Pembahasan}

Puskesmas (Pusat Kesehatan Masyarakat) adalah fasilitas pelayanan kesehatan yang menyelenggarakan upaya kesehatan masyarakat dan upaya kesehatan perseorangan tingkat pertama, dengan lebih mengutamakan upaya promotif dan preventif diwilayah kerjanya.

Berdasarkan penelitian yang dilakukan di puskesmas cakranegara yang terletak di Jln. Brawijaya 3B Mandalika, Kecamatan Sandubaya, Kota Mataram. Penelitian yang saya ambil yang berjudul Profil Penggunaan Obat Antibiotik di Puskesmas Cakranegara Periode Januari-Juni 2021 yang di dapat dari data LPLPO (Laporan Pemakaian Dan Lembar Permintaan Obat) yang berisi tentang pemakaian Antibiotik di Puskesmas Cakranegara pada Periode Januari-Juni 2021.

Hasil penelitian menunjukkan bahwa penggunaan Antibiotik di Puskesmas Cakranegara dari periode Januari-Juni 2021 meliputi, Amoxicillin tablet dari Bulan Januari-Juni 2021 yaitu pada Bulan Januari 9.170, Februari 9.224, Maret 10.786, April 7.301,Mei 5.643, dan Juni 5.085. Kotrimoxazole tablet dari Bulan JanuariJuni 2021 yaitu pada Bulan Januari sebanyak 915, Februari 888, Maret 1.424, April 359, Mei 345, dan Juni 230. Ciprofloxacin dari Bulan Januari-Juni 2021 yaitu Januari sebanyak 920, Februari 559, Maret 394, April 338, Mei 222, dan Juni 262. Amoxicillin sirup kering dari Januari sebanyak 162, Februari 197, Maret 233, April 142, Mei 79, dan pada Bulan Juni 37. Metronidazole dari Bulan Januari-Juni 2021 yaitu pada Bulan Januari sebanyak 205, Februari 132, Maret 19, April 45, Mei 75, dan Juni 89. Kotrimoxazole sirup dari 
Bulan Januari-Juni 2021 yaitu pada Bulan Januari sebanyak 85, Februari 85, Maret 124, April 78, Mei 35, dan Juni 29. Kloramfenikol kapsul dari Bulan Januari-Juni 2021 yaitu pada Bulan Januari sebanyak 20, Februari 20, Maret 120, April 20, Mei 0, dan Juni 145. Oxytetrasiklin dari Bulan JanuariJuni 2021 yaitu pada Bulan Januari sebanyak 63, Februari 66, Maret 58, April 38, Mei 25, dan Juni 19. Gentamisin salep kulit dari Bulan Januari-Juni 2021 yaitu pada Bulan Januari sebanyak 61, Februari 1, Maret 0, April 26, Mei 34, dan Juni 20. Kloramfenikol tetes telinga dari Bulan Januari-Juni 2021 yaitu pada Bulan Januari sebanyak 13, Februari 18, Maret 39, April 26, Mei 7, dan Juni 3. Ampisillin dari Bulan Januari-Juni 2021 yaitu pada Bulan Januari sebanyak 16, Februari 17, Maret 17, April 9, Mei 11, dan Juni 10. Azitromicin dari Bulan Januari-Juni 2021 yaitu pada Bulan Januari sebanyak 10, Februari 2, Maret, 2, April 0, Mei 0, dan Juni 0.

Jadi jumlah rata-rata penggunaan antibiotik dari bulan Januari-Juni 2021 yaitu Amoxicillin tablet sebanyak 47.209, Kotrimoxazole tablet sebanyak 4.161, Ciprofloxacin sebanyak 2.695, Amoxicillin sirup kering sebanyak 850, Metronidazole sebanyak 515, Kotrimoxazole sirup sebanyak 436, Kloramfenikol kapsul sebanyak 326, Oxytetrasiklin sebanyak 269, Gentamisin salep kulit sebanyak 142, Kloramfenikol tetes telinga sebanyak 106, Ampisillin sebanyak 80 dan Azitromicin sebanyak 14.

Jadi, total keseluruhan penggunaan obat Antibiotik di Puskesmas Cakranegara sebanyak 56.785 .

Penggunaan Antibiotik banyak digunakan pada Bulan Januari-Juni Tahun 2021 dikarenakan penyakit Infeksi dan Non Infeksi misalnya seperti penyakit ISPA (Infeksi Saluran Pernafasan Atas) terutama pada situasi pandemi COVID-19. Meskipun ada beberapa penyakit pada saluran pernafasan yang tidak selalu memerlukan Antibiotik, tetapi jika penyakit tersebut sudah melewati tiga hari maka Dokter tetap meresepkan penggunaan Antibiotik. Sedangkan penyebab terjadinya peningkatan dan penurunan penggunaan Antibiotik di Puskesmas Cakranegara, tergantung pada pola penyakit dan jumlah kunjungan pasien setiap bulannya.

\section{Kesimpulan}

Berdasarkan hasil dan pembahasan penelitian yang telah dilakukan mengenai Profil penggunaan obat Antibiotik di Puskesmas Cakranegara dapat di Tarik kesimpulan bahwa :

1. Jenis Antibiotik yang digunakan di Puskesmas Cakranegara meliputi Amoxicillin tablet, Kotrimoxazole tablet, Ciprofloxacin, Amoxicillin sirup kering, Metronidazole, Kotrimoxazole sirup, Kloramfenikol kapsul, Oxytetrasiklin, Gentamisin salep kulit,
Kloramfenikol tetes telinga, Ampisillin, dan Azitromicin.

2. Sediaan Antibiotik yang digunakan di Puskesmas Cakranegara meliputi sediaan Tablet, Sirup, Salep, Tetes telinga.

3. Antibiotik dengan pemakaian terbanyak yaitu Amoxicillin tablet sebanyak 47.209 sedangkan pemakaian Antibiotik paling sedikit yaitu Azitromicin sebanyak 14.

\section{Daftar Pustaka}

Amin, Lukman Zulkifli, 2017, Pemilihan Antibiotik yang Rasional, Fakultas Kedokteran Universitas Indonesia.

Depkes, RI. 2016. Kebijakan Obat Nasional. Jakarta

Depkes, RI. 2018. Peraturan Menteri Kesehatan Tentang Pedoman Umum Penggunaan Antibiotik, Kementrian Kesehatan Republik Indonesia. Jakarta

Depkes, RI. 2019. Profil Kesehatan di Indonesia. Jakarta

Farida, H. 2016. Pengawasan Penggunaan Antibiotik Upaya Mencegah dan Mengendalikan Resisitensi Antibiotik. Universitas Diponegoro

Hadi U, 2016. Resistensi Antibiotik, Buku Ajar Ilmu Penyakit Dalam. Jakarta: Pusat Penerbitan Departemen Ilmu Penyakit Dalam FKUI

Hadi U, et al. 2019. Antibiotic usage and antimicrobial resistance in Indonesia. $\mathrm{PhD}$ desertation Leiden.

Hartono. 2020. Promosi Kesehatan RI. Jakarta

Juwono \& A. Prayitno. 2019. Terapi Antibiotik. Jakarta: Gramedia

Katzung, G. 2018. Penggolongan Antibiotik Penisilin. Jakarta: Salemba Medika

Kee, Joyce. L \& R. Hayes, Evelyn. 2018. Fakmalogi, Pendekatan Proses Keperawatan. Jakarta: EGC

Kemenkes RI, 2016. Peraturan Menteri Kesehatan tentang Pedoman Umum Penggunaan Antibiotik. Jakarta : Menkes RI.

Kemenkes, 2018. Pedoman Umum Penggunaan Antibiotik. Jakarta

Kemenkes, 2018. Peraturan Menteri Kesehatan No 30 tentang Standar Pelayanan Kefarmasian di Puskesmas. Jakarta

Kemenkes, 2020. Pengelolaan Obat Publik dan Perbekalan Kesehatan di UPTD Instalasi Farmasi Kabupaten. Jakarta

Notoatmodjo, Soekidjo. 2017. Metodologi Penelitian. Jakarta: Rineka Cipta

Notoatmodjo, Soekidjo. 2018. Metodologi Penelitian. Jakarta: Rineka Cipta

Richard A, Hervey. 2020. Farmakologi Ulasan Bergambar. Jakarta. EGC

Dr.Soetomo. 2018. Panduan Penggunaan Antibiotik Profilaksis dan Terapi. Surabaya : RSUD Dr.Soetomo 
Setiabudy, Rianto. 2018. Farmakologi dan Terapi. Jakarta: Graya Baru

Setiabudy, Rianto. 2019. Farmakologi dan Terapi. Jakarta: Graya Baru

Setiadi. 2016. Konsep Penulisan Riset Keperawatan , Edisi Pertama. Yogyakarta: Salemba Medika

Siregar, Charles. J.P. 2017. Teknologi Farmasi, Sediaan Tablet Dasar-Dasar Praktis. Jakarta: EGC 